\title{
Vine and Woman-One of the Cardinal Symbols of Georgian Identity (Ethnological Research)
}

\author{
Nino Ghambashidze ${ }^{a}$
}

\begin{abstract}
At the center of one of the ancient Georgian mythological narratives, we find a figure of the great mother Nana in the land of Batonebi. It is one of the images of paradise, suffused with eternal light, ruby marani (location for storing wine in special pitchers), and a poplar growing nearby. This poplar is the tree of life, the tree of immortality on which, in some variants, vine is climbing up. In the fourth century, as the tradition and chronicle says, before coming to Georgia for preaching Christianity, St. Nino was given a vine cross by the Blessed Virgin. In the twelfth century, the Georgian king Demetre I wrote a hymn entitled "You Are the Vineyard" which is dedicated to Blessed Virgin, the patroness of Georgia. If we look at the way in which the religious mentality of Georgians developed, we can notice a line of symbols: the vine, representing the tree of life/cross, and the holy woman (the great mother Nana, the Holy Virgin, and St. Nino), who is connected with it. The vine cross, the "Georgian Cross" that Our Lady gave to St. Nino is one of the obvious images of Georgian identity containing pre-Christian worldviews as well.
\end{abstract}

\section{Keywords}

Ethnology, religion, mythology, linguistics, ethnomusicology

It is well acknowledged that Georgia is the country of vine and wine. The eighteenth-nineteenth century Swiss botanist Augustin Pyrame de Candolle noted that South Caucasus, Georgia is "the place where wild vine was first cultured and wine was made of grape juice"1 (Ghudushauri 2010: 435). Modern archaeological excavations have unearthed "the earliest biomolecular archeological evidence for grape wine and viniculture from the Near East" which was dated to 6000-5800 BC (McGovern et al. 2017).

Officially, 584 species of vine were cultivated in Georgia (Kobaidze 2014: 4). There were many ways of vine cultivation, making wine from grapes. A large number of rituals were dedicated to vine cultivation, development of viticulture, and wine-making.

Caring about vine and making wine has been men's activity from primordial times. Women were not allowed to care about zedashe ${ }^{2}$ or marani $^{3}$. Woman would enter marani to light candle, she had to be pure i.e. have no menstruation. If she accidentally touched zedashe, she should sprinkle holy water. If there was no adult man in the family, only a widow was allowed to open or wash the zedashe pot (Topuria 1984: 34).

But, completely different is the situation with vine and woman in the Georgians' religious beliefs.

aIvane Javakhishvili Tbilisi State University, Georgia

\section{Correspondent Author:}

Nino Ghambashidze, A. Kazbeki avenue \#29a, 0177, Tbilisi, Georgia 


\section{GREAT MOTHER NANA}

“A poplar tree has grown in our Master's yard, Grapes grow on top of it; it has come down to eat them, Young women and men, who did not eat the grapes died untimely" (Ochiauri 1988: 18).

The text of this ritual round dance with musical accompaniment was disseminated in many variants and was an inseparable component of religious festivals in almost all parts of East Georgia. According to $\mathrm{V}$. Bardavelidze, the story of vine wound around poplar tree narrated in this ritual verse, denotes maghlari-one of the types of vineyard; and that vine wound round the poplar is the tree of life (Bardavelidze 2007: 67). This viewpoint disseminated among people is also encountered in official historical source. One of the parts of Kartlis Tskhovreba (Life of Kartli) narrates about St. Nino's coming to Mtskheta, visit to the King's paradise or garden, where Svetitskhoveli was constructed later. St. Nino meets Anastasia (Anastos in some sources), the gardener's wife, who welcomes her warmheartedly and stays at her for certain time. It turns out that the gardener and his wife had no children, which worries them. St. Nino has a vision of a man illuminated with holy light who tells her to enter the garden where she will find a "small" babilo with sweet smell. "Take the ground under it, give it to the spouses to eat; she did so and the couple gave birth to children; they became St. Nino's disciples and converted to Christ's belief" (Prince Vakhushti 1973: 80, 84). Babilo is the name of vineyard that climbs tree. Sulkhan-Saba Orbeliani defines babilo (tree) as high grapevine-yard; its synonym is dobilo ${ }^{4}$ (Orbeliani 1991: 87). On the monastic lands in Kvemo Kartli, Shavshet-Klarjeti, there were a lot of high grapevines-babilos. Some monasteries even had special clay vessels for babilo wine (Lekiashvili 1972: 57).

According to Georgian mythological narratives, fairy tales, and ritual songs, in the Georgians' beliefs, one of the pictures of Eden looked like great mother
Nana's place of residence. In legends, this is called the land of batonebi (masters); in songs - the garden of masters and in fairy tales - the garden of the Sun. In this garden also appear other mythological characters: mother of the Sun and Moon, three daughters of Sun, Elia - the Deity of Thunderstorm, wolf, and Golden ram. In this garden, simultaneously some tress bloom, some have ripe fruits, and leaves are falling from some tress.

The land of masters is hard to get to, beyond nine mountains and nine seas, beyond thorny forest. According to some legends, the masters came from the White Sea. Their country is located on rocky coast, overlooking the sea or on the island in the sea. The country is surrounded by high fortress with big doors, locked beyond the fortress walls. In the land of masters, there are springs with crystal pure water, rivers of honey and milk, and a lot of waterfalls. The Sun sheds rainbow colors on everything. Here, there are masters' towers and big houses. In this country and garden together with masters live the souls of the deceased who passed away due to infectious diseases. According to Svan version, on the rock where the master's country is located, overlooking the sea, there is meadow covered with flowers. There is a large river on the meadow, where there is great mother, masters' mother. She is naked with white body and big breast. According to song verses, great mother Nana lives together with masters in the garden of violets, roses, and white mulberry. In Vera Bardavelidze's opinion, open marani was the one near which grew a poplar tree. Birds sit and chirp in this tree (Bardavelidze 2007: 76-78). "In Georgian mythological belief poplar is the tree of life growing in Eden ('as poplar growing in Eden' reads 'Knight in the Panther's Skin'). In folk verse grapes grow on the top of the tree, he who eats these grapes will be protected from all harm"-writes Zurab Kiknadze. According to the material accessible for us, the poplar tree of great mother Nana and masters grows near open marani, but there is no vine wound round it. It is known that both kinds of marani 
were the favorite places for partying. There were zedashe vessels in both maranis. The marani of the masters' land and the poplar tree belong to great mother Nana, with different kinds of wine kept there: red, white, and pink (Bardavelidze 2007: 78). As if this wine is made from the grapes growing on the poplar tree, similar to the monastic wines in Shavsheti and Kvemo Kartli. It looks as if mythological narrative misses a small chain where babilo should be mentioned. "Our master's palace" should definitely mean Lord's/Master's place, but the country of great mother Nana and her deities is also called Masters' country. On its part, "Master's yard" is the same as Eden. The mythological narrate clearly tells that tree of life (poplar) in Masters' land, as well as the beverage of immortality wine - made from the grapes growing on the tree of life belong to great mother Nana.

\section{SAINT NINO}

Time passed and in the fourth century, St. Nino came to Georgia to preach Christianity holding grapevine cross given to her by the Holy Virgin Mary ("Nino's Life" 1991: 209). From this standpoint, particularly noteworthy is The Life of St. Nino by Arsen of Ikalto. The author writes that when living in Jerusalem, St. Nino hotly prayed day and night in front of the Holy Virgin's icon. Once she was "excitedly praying" (Natroev 1900: 124) at Zion Church, when Holy Virgin appeared in front of her and told her to go to Northern country, "go and fearlessly teach the truth"! "But I am a woman and I do not speak foreign language?" Nino answered. Then the Virgin cut the rods off the grapevine growing on her grave (Mgaloblishvili 1991: 44; Natroev 1900: 125), made a cross, gave to Nino and said "With this you will defeat the evil, insidiousness, and your sermons will be fruitful, I will be for you a shield". "Thus St. Nino's cross-grapevine cross, became the symbol of Georgian church, sign and miracle of Georgian orthodoxy. It embodies the son-Jesus Christ and his mother-Holy Virgin Mary (cross, symbol of the Lord; vine, symbol of the Virgin). Thus, vine cross connected St. Nino, Holy Virgin, and Georgia" (Makharashvili 2009: 218-219)—writes Soso Makharashvili. On our part, we would like to add that the fact of handing vine cross to St. Nino in Jerusalem, may be once again stressing that Georgian church originated in Jerusalem. The cross of vine, growing on Holy Virgin's grave, born near the Mother Church in Jerusalem, was preserved in Svetitskhoveli (mother church of Kartli constructed by Mirian) until 541 (Makharashvili 2009: 218). In Svetitskhoveli, constructed on the spot where, according to church tradition, the Holy Tunic weaved by the Holy Virgin is buried and which, similar to Zion Mother Church is connected with the disciples. In Svetitskhoveli, named after the pillar carved from the tree growing on the Christ's tunic and which is connected with the woman's (Sidonia's) grave. According to the second narrative, Mirian put this cross into the cross erected on the Golgotha of Mtskheta and which later was placed in Jvari (Cross) church in Mtskheta (Natroev 1900: 129, 134). Today, after many adventures, St. Nino's grapevine cross is at Sioni cathedral church in Tbilisi.

As mentioned above, the Apostle St. Nino lived in the house of the gardener in Mtskheta; and with the help of the ground under babilo growing in this garden $^{6}$, the childless couple gives birth to children, according to the source once when praying St. Nino had a vision. The birds bathed in the river, flew to "Eden", pinched babilo, "ate" the garden flowers, and appealed to Nino (Gigineishvili and Giunashvili 1979: 336). The official source displays archetypal picture of Eden with the tree of life (babilo or high grapevine), birds of paradise, and holy woman, mother Nino, thanks to whom Kartli was reborn via Christianity. If in the mythological story narrated in the verse of ritual song, the youth had to eat babilo fruit in order to live, in this case, it was necessary to eat the ground from 
which babilo had grown (Gigineishvili and Giunashvili 1979: 336). The paradise where high grapevine babilo grows, surrounded by birds, is also depicted on the frescoes of Georgian churches (Siradze 2014: 89).

Revaz Siradze mentions that St. Nino embodies "Mother God" i.e. old Georgian pagan deity or her image disseminated in Kartli (Siradze 1987: 99-100). Undoubtedly, the images of pre-Christian collective thinking emerge from time to time. One such image may relate to the tree of life/vine/babilo/cross and woman (deity, Mother of God, Saint). But in the first place, Conversion of Kartli is a historical chronicle and tells about historical events. It is noteworthy that St. Nino is a historical figure. As Zurab Kiknadze writes, the royal garden described in Conversion of Kartli does not denote the heavenly paradise, but is a technical term. The scholar also explains that pari-daeza was the name of Persian garden and from here, the word acquired the meaning of paradise (Latin paradises, Italian paradiso, English paradise, etc.). For Persian garden, essentially important are aroma and fruiting trees. According to Iranian mythos, the first King Jima sat in the garden. This garden was entire Earth. Garden, in its meaning, is the best place on the Earth. However, the mythos of King-gardener originated in Mesopotamia. The Royal garden of Mtskheta is the garden of Eden on the earth, which in Zurab Kiknadze's words turns into "garden of salvation" or church. The scholar draws parallel with Mount Athos, which is "Holy Virgin's property on the Earth" and is referred to as "Holy Virgin's Garden". According to one narrative, Holy Virgin liked Mount Athos and asked Jesus to give it to her. After the request, voice from Heaven said: "My this place be in your possession and your garden, and Paradise and Heaven for those striving for salvation!" (Kiknadze 2009: 87-89, 91-92).

King of Kartli Mirian-of Iranian origin, a descendant of Sasanian Dynasty, constructed Svetitskhoveli Cathedral-the Georgians' greatest place of worship in the Royal garden-full of aromatic and fruiting trees, decorated with cedar he had brought from abroad. Iranian Mirian masters the cultural and religious heritage of Pharnavaz's Dynasty. Lela Pataridze duly notes that the Georgians accepted Persian Prince because he, as King of Kartli, loved Georgian language, paid respect to the religion of Georgians, and “decorated" Parnavaz's grave (Pataridze 2009: 22-23).

St. Nino born in Greek surrounding and educated as Christian in Jerusalem sets off to the Kingdom of Kartli, for a certain time lives in Royal garden, in Mtskheta, makes miracles, and has a vision about her future activity as of a missionary. The miracle is connected with earthly life, fertility, and the vision with salvation. Both are connected with eating: Earthly life is born via eating the vine ground, spiritual—via eating fruit of that vine, which, in our opinion is embodied in Nino's cross and becomes the clearest, most capacious, comprehensive image. Miraculous, life-giving babilo obviously grafts the Iranian-style royal garden on Georgian soil.

Mikheil Tarkhnishvili writes:

Old pagan viewpoint according to which the meaning of a slave and woman was objected, moved Nino to the back for certain time, but the awakened religious-national self-consciousness, which found the support of equality of people and woman's dignity in Christianity, brought her back and together with her gifted us with the twelfth century "Golden Era". (Tarkhnishvili 2008: 116)

In the twelfth century, King Demetre I of Georgia dedicated a hymn in iambic meter entitled "Thou Art a Vineyard" (Georgian shen khar venakhi) to Holy Virgin, the patroness of Georgia. This hymn has survived to this day as a chant:

You are a vineyard newly blossomed

Young, beautiful, growing in Eden

A fragrant poplar sapling in Paradise

May God adorn you. No one is more worthy of praise

You yourself are the sun, shining brilliantly. (Sulava 2003: 278) 
In this deeply Christian hymn, it is hard not to see the echo of great mother Nana, her paradise, poplar tree, high grapevine, and eternal life: That mother Nana's image originated in the period of astral cults, more precisely in the period of the Sun's development (Bardavelidze 2007: 93). Not to remember the narrative from Georgian sources that from the vine growing on Holy Virgin's grave ${ }^{7}$ (Kekelidze 1912: 200, 208), St. Mary made a cross for St. Nino. Not to remember the fresco "Holy Virgin in Paradise" from Nabakhtevi temple, with babilo depicted on it. Or not to remember Porphyrius Uspensky's notice that the monks at the Holy Monastery of Iviron on Mount Athos sang "Nennena" in memory of the Mother of God ("My Consolation" as translated by Uspensky). He also mentions that Holy Virgin sang "Nennena" to the divine baby in the cradle (Uspenski 1877: 72). Not to remember sanctuary nanas, sung by women in the church yards, or Georgian song masters and singers (Varlam Simonishvili, Rema Shelegia, and others) who on deathbed asked their family to sing nana for them (Kalandadze and Urushadze 2004: 79; Kalandadze and Urushadze 2007: 116).

Also interesting is the fact that in his notice, Uspensky writes nenena with double " $\mathrm{n}$ " as nennena. According to M. Chukhua's research, -nen-, -nen-al meant "language", the same with -nin-, nina/l, and -nin. In Kartvelian languages, Nena-i/nene-i, nana, and nan denote mother, grandmother, great mother, and grandma (Chukhua 2000-2003: 143, 164-165). If we discuss the word nen(-)nena from this standpoint, it may mean "said by mother, great mother, grandmother". If our consideration is correct, nennena may imply lullaby sung by mother to her child. In Georgia, alongside sing a song, we say "say a song". Thus nennena sung by the monks on Athos may mean Holy Virgin's lullaby sung at Jesus' cradle. The image of the Holy Virgin sitting and singing at the cradle so much resembles the image originated from the Georgians' collective consciousness. When discussing great mother Nana's cult, V. Bardavelidze duly mentioned that if the mothers of other peoples hold the children in hands, in Georgian archetypal image, great mother sits at the cradle and sings to the child (Bardavelidze 2007: 96). It also must be said that in Georgia, cradle was made of vine too (Makharadze 2014: 63). On our part, we would like to add that the constituent of this archetypal image for the Georgians is not only mother/goddess, vine/tree of life/wine, but also song, presented as lullaby. Georgian people gave the name of great mother Nana to mother and prayer to be sung at the cradle and shrine.

As Nestan Sulava notes, in patristics, the universe is acknowledged via symbol as symbol links visible and invisible worlds. "In Middle Ages when applying pre-Christian cultural heritage the symbolic-allegoric form becomes chief means of artistic-expression". "In Georgian world this was well-manifested by the symbols of sun and vine, pagan cult and beliefs laid in the foundation of their development, dissemination and development of Christianity added Christian character to it" (Sulava 2003: 31).

In 1995, Archil Mindiashvili, deacon of Tbilisi Petre-Pavle (St. Peter's and Paul's) Church, had a desire to create a new icon based on the symbols of "Thou Art a Vineyard" and a fresco from Cappadocia. "Embodied on this icon should be 'vineyard' and 'sapling', as well as 'tevani venakhisa' or the mystery of the personification of the second person of the Trinity by reasonable mind, here I also thought of St. Nino's vine cross..."-writes Archil Mindiashvili (Mindiashvili 2006: 4). The icon immediately provoked love and hope in people.

Together with Mary Magdalene and St. Thekla, St. Nino is among the few women, whose merit equals with that of the apostles. Opinions have been expressed concerning Georgia's conversion by woman. According to them, one of the reasons for this is that Holy Virgin is the patroness of Georgia and also that the conversion by a woman would make the Lord's power more clear for the country inhabited by fierce and savage people (Natroev 1900: 125-126). On our 
part, we would like to add that during the long formation process of Georgian self-consciousness, the attitude to woman religious as well as secular acquired particular character. This is the country where women were governors and even sovereigns, where five women from the Social Democratic Party in 1919 became the members of the Constituent Assembly of Georgia, one of the first in the history of parliament, and where women's public activity would never be strange and unprecedented.

\section{CONCLUSIONS}

We consider the tree of life/cross presented as vine and holy woman (great mother Nana, Holy Virgin, and St. Nino) linked with it, is one of the cardinal symbols of the Georgians' religious thinking. In collective consciousness, it appears in various forms as an archetype. Collective thinking which contains in itself cardinal symbols of nation, transpierces all spheres of human life. We think that the vine cross, Georgians' cross, according to tradition given to St. Nino by the Holy Virgin is one of the most distinct images of Georgian identity, in which Georgians' pre-Christian worldview is merged with the Christian worldview and which emerged as a result of the encounter with foreign cultures on Georgian soil.

\section{Notes}

1. The quote is taken from Tinatin Ghudushauri's article. Ghudushauri, T. "Viticulture." In Ethnography/Ethnology of Georgia (Topchishvili 2010: 435).

2. Zedashe is a clay pot for certain shrine where the best wine for ritual purposes is kept.

3. According to Sulkhan-Saba Orbeliani, marani is a place to keep victual, wine in clay pots, and also to perform baptism and wedding rituals.

4. Different explanations are provided in different inventories: high vine, tree vineyard, long vine (tree), dobilo, and vineyard on the tree.

5. The place of Holy Virgin's passing is connected with Zion Church (Mgaloblishvili 1991: 44; Natroev 1900: 125).
6. Natroev writes that this was the King's vineyard (Natroev 1900: 134).

7. According to the narrative, Holy Virgin passed away in the house, which is connected to Zion Mother Church and as it is very well known, her grave is in Gethsemane (Kekelidze 1912: 200, 208).

\section{References}

“Nino’s Life." 1991. In Georgian Prose, I. Tbilisi: Sabchota Sakartvelo.

Bardavelidze, V. 2007. Graphic Art of Ancient Religious Beliefs and Rituals of Georgian Tribes. Tbilisi: Caucasian House.

Chukhua, M. 2000-2003. The Kartvelian Comparative Dictionary. Tbilisi: Universali.

Ghudushauri, T. 2010. "Viticulture." In Ethnography/Ethnology of Georgia. Tbilisi: Universali.

Gigineishvili, B. and E. Giunashvili. 1979. Collection From Shatberdi.Tbilisi: Metsniereba.

Kalandadze, N. and L. Urushadze. 2004. Masters of Georgian Folk Song, Guria I. Tbilisi: Sakartvelos Matsne.

- 2007. Masters of Georgian Folk Song, Samegrelo II. Tbilisi: Sakartvelos Matsne.

Kekelidze, K. 1912. Seventh Century Jerusalem Canon (Georgian Version). Saint Petersburg: Typography of the Emperor's Academy of Science.

Kiknadze, Z. 2009. Georgia on Its Way to Christianity: Human and Holiness. Tbilisi: Caucasian House.

- 2014. "Vine and Wine in Folk Art." In Vine of Life. Tbilisi: Georgian Wine Association.

Kobaidze, T. 2014. Reference Book of Georgian Vine Species. Tbilisi: Library of the National Agency of Wine.

Lekiashvili, A. 1972. Thou Art the Vine. Tbilisi.

Makharadze, N. 2014. "Vine and Georgian Traditional Music." In Vine, Tree of Life. Tbilisi: Georgian Wine Association.

Makharashvili, S. 2009. "On the Problem of St. Nino, Grapevine Cross and Virgin Mary, the Main Protector and Intercessor of Georgia." In The Life of Saint Nino and Conversion of Kartli. Tbilisi: The Institute of Literature.

McGovern, P., M. Jalabadze, S. Batiuk, M. P. Callahan, K. E. Smith, G. R. Hall, ... D. Lordkipanidze. 2017. "Early Neolithic Wine of Georgia in the South Caucasus." PNAS 114(48):E10309-E10318.

Mgaloblishvili, T. 1991. The Klarjeti Polycephalon. Tbilisi: Metsniereba.

Mindiashvili, A. 2006. Miracle-Working Icon of the Holy Virgin "Thou Art a Vineyard", 1995-2006. Tbilisi.

Natroev, A. 1900. Mtskheta and Svetitskhoveli Cathedral. Tiflis: Typography of Kozlovski, T. P. 
Ochiauri, A. 1988. Calendar of the Georgian People's Folk Festivals. Khevsureti (Arkhoti Community). Tbilisi: Metsniereba.

Orbeliani, S.-S. 1991. Georgian Lexicon, I. Tbilisi: Merani.

Pataridze, L. 2009. "Political and Cultural Identities in the 4th-8th cc." In Georgian Community: The World of Life of Kartli. Tbilisi: Caucasian House.

Prince Vakhushti. 1973. Kartlis Tskhovreba IV. Description of the Kingdom of Georgia.Tbilisi: Metsniereba.

Siradze, R. 1987. Georgian Hagiography. Tbilisi: Nakaduli.

—. 2014. "Vine and Wine in Georgian Write." In Vine of Life. Tbilisi: Georgian Wine Association.

Sulava, N. 2003. The Twenteeth-Thirtinth Century Georgian Hymnography. Tbilisi: Merani.

Tarkhnishvili, M. 2008. "The Legend of Saint Nino and the History of Georgian National Consciousness." In St. Nino. Tbilisi: Artanuji.
Topuria, N. 1984. From the History of the Georgian People's Mode of Life. Tbilisi: Metsniereba.

Uspensky, P. 1877. First Journey to the Monasteries and Sketes of Athos. Kiev: Typography of Frantskevich, V. L. Retrieved January 28, 2015 (http://nooks.e-heritage.ru/ book/10076618).

\section{Bio}

Nino Ghambashidze, Doctor of History, senior scientific researcher, Department of the Ethnology of Georgia, Ivane Javakhishvili Institute of History and Ethnology, Ivane Javakhishvili Tbilisi State University, Georgia, invited teacher of V. Sarajishvili Tbilisi State Conservatoire; research fields: ethnology, religion, psychology of religion, art history, linguistics, ethnomusicology. 